\title{
Would the Public Support a Ban on Smoking in Public Places? - A Survey of Local Opinion in the North East of England
}

\author{
Sadia Ahmed, Avinash Aujayeb, Emma Cowens, Adam Evans, \\ Felicity Gent, BSc, Jean Adams*, BMedSci, MBBS, PhD, Peter Heywood, BM, \\ MSc, MFPH, Martin White, MBChB, MSc, FFPH, MD
}

\begin{abstract}
The purpose of study is to determine the degree of support for a general ban on smoking in public places and bans on smoking in specific locations amongst adults living in the North East of England. To assess the variation in support for smoking bans by smoking status and socio-demographic factors. Procedures: After appropriate training, ten medical students conducted interviews with members of the public in city centre locations. Interviewers adhered to a structured schedule and all participants gave informed consent. Quota sampling techniques were used to obtain a sample representative of the wider population in terms of age, gender and occupational social class. Main findings: Interviews were conducted with 538 individuals of whom $338(63 \%)$ stated that they would support a general ban on smoking in public places. Support for a ban varied by smoking status and social class but not by gender or age group. Of the specific locations mentioned, support was greatest for smoking bans in restaurants and cafes (83\%), shopping malls (72\%) and workplaces (72\%) and lowest for smoking bans in pubs and clubs $(37 \%)$, the home $(27 \%)$ and outdoor public places (23\%). Conclusions: Local support for bans on smoking in public places in the North East of England is high - particularly in relation to bans in restaurants and cafes, shopping malls and workplaces. Introduction and enforcement of smoking bans in these locations would not be expected to meet with great opposition and may have a positive influence on public health.
\end{abstract}

KEY WORDS: Tobacco control, smoking bans, public opinion

\section{INTRODUCTION}

Worldwide, it is estimated that there are 4.9 million tobacco related deaths per year (1). In the UK, $27 \%$ of the population smokes and approximately 120000 individuals die annually from smoking related diseases (2). In addition to the direct effects on those who smoke, the indirect effects of smoking in terms of second hand

*To whom correspondence should be addressed: Jean Adams, research fellow, BMedSci, MBBS, PhD, School of Population and Health Sciences, University of Newcastle upon Tyne, UK, NE2 4HH, tel: +44 191222 8124, fax: +44 1912228211

email: j.m.adams@ncl.ac.uk smoke, or passive smoking, include an increased risk of lung cancer, ischaemic heart disease and respiratory disease in individuals regularly exposed to environmental cigarette smoke, especially children (2).

One intervention to decrease smoking and exposure to second hand smoke is the introduction of restrictions, or bans, on smoking in public places (3). Such a policy is topical in the UK with recent calls from both the Chief Medical Officer (4). and the British Medical Association (5) for comprehensive bans enforced by law. Bans on smoking in public places would be expected not only to protect the health of those 
Table 1. The Registrar General's social classes

\begin{tabular}{llll}
\hline Social class & Description & Examples & Dichotomous classification \\
\hline I & Professional occupations & $\begin{array}{l}\text { Accountants, civil or electrical engineers } \\
\text { doctors, lawyers, pharmacists, scientists, } \\
\text { architects, vets, clergy }\end{array}$ & Non-manual \\
\hline II & $\begin{array}{l}\text { Managerial, technical or } \\
\text { intermediate occupations }\end{array}$ & $\begin{array}{l}\text { Marketing and sales managers, teachers, } \\
\text { journalists, nurses, taxi drivers, hotel or pub } \\
\text { managers, musicians, actors }\end{array}$ & Non-manual \\
\hline III non manual & $\begin{array}{l}\text { Non-manual skilled } \\
\text { occupations }\end{array}$ & $\begin{array}{l}\text { Clerks, secretaries, shop assistants, } \\
\text { cashiers, driving instructors, restaurant managers }\end{array}$ & Non-manual \\
\hline III manual & $\begin{array}{l}\text { Manual skilled } \\
\text { occupations }\end{array}$ & $\begin{array}{l}\text { Carpenters, goods van drivers, joiners, } \\
\text { cooks plasterers, welders, fitters, decorators }\end{array}$ & Manual \\
\hline IV & $\begin{array}{l}\text { Partly skilled manual } \\
\text { occupations }\end{array}$ & $\begin{array}{l}\text { Security guards, machine tool operators, } \\
\text { farm workers, assembly line workers, caretakers, } \\
\text { care assistants, bar staff }\end{array}$ & Manual \\
\hline V & $\begin{array}{l}\text { Unskilled manual } \\
\text { occupations }\end{array}$ & $\begin{array}{l}\text { Building labourers, refuse collectors, } \\
\text { cleaners, porters }\end{array}$ & Manual \\
\hline
\end{tabular}

Occupational social class was measured using the Registrar General's social class of the main wage earner in the household in which the respondent lived. This commonly used classification system assigns individuals to one of six social classes. As is common in small surveys, these six classes were then collapsed into a dichotomous classification.

involuntarily exposed to second hand smoke in, for example, workplace settings but also to encourage active smokers to quit (6-8). One estimate is that a total ban on smoking in workplaces in the UK will reduce smoking rates from $27 \%$ to $23 \%$ - an effect size similar to that associated with a doubling of the retail price of cigarettes (2). Legally enforced restrictions on smoking in public places have recently been introduced in New York, California, Delaware, Florida and Winnipeg.

However, smoking bans are not without their critics. Smoker's rights groups have suggested that bans on smoking in public places infringe the civil liberties of smokers (9) and members of the hospitality industry frequently raise, perhaps unfounded, concerns over the effect of smoking bans on their business (10).

In New York, where a ban on smoking in all bars, cafes and restaurants was introduced in March 2003, proprietors are responsible for enforcing the ban in their establishments - with a potential $\$ 400$ fine for those who fail to maintain a smoke free environment. Anecdotal evidence suggests that bartenders dislike this 'policeman' role (11) and a recent review concluded that "these policies seem to work best when there is a strong social consensus against smoking in public places and, therefore, self enforcement of the restrictions" (3).

In spring 2003, journalists from the British Broadcasting Corporation (BBC) in the North East and Cumbria approached the School of Population and Health Sciences at Newcastle University, UK concerning the production of an item for a television news magazine programme on public views on bans on smoking in public places in the North East of England. As no recent, local data from across the region was available on this topic, the present study sought to investigate local public support for bans on smoking in public places and the variation, if any, on stated support by social and demographic factors.

\section{METHODS}

Face-to-face interviews were performed with members of the public in some of the major conurbations in the North East of England (Newcastle upon Tyne, Gateshead, Sunderland and Middlesbrough). Ten medical students were trained to act as interviewers by MW. Interviews were conducted at five city centre locations during two weekday lunch hours in July 2003. After explaining the purpose of the study and confirming that all responses would be anonymous and confidential, individuals were asked if the would agree to take part in the survey.

An interview schedule was used to collect information on gender, age, current smoking status and occupational social class (Table 1). Participants were then asked if they would support a ban on smoking in public places and their main reasons for supporting or opposing such a ban. Reasons for supporting or opposing a ban were grouped into a number of categories generated by the authors pre-hoc. If stated reasons did not fall into any of these categories, they were categorised as 'other' and recorded verbatim and grouped into further categories post-hoc. Finally, participants were asked if they would support a ban on 
Table 2. Distribution of the population of the North East of England by age group, gender and occupational social class as a percentage and as applied to a representative sample of 550 individuals

\begin{tabular}{|c|c|c|c|c|c|c|c|c|c|c|}
\hline \multirow[t]{2}{*}{ Age } & \multicolumn{2}{|c|}{$\begin{array}{l}\text { Male } \\
\text { Non-manual }\end{array}$} & \multicolumn{2}{|c|}{ Manual } & \multicolumn{2}{|c|}{$\begin{array}{l}\text { Female } \\
\text { Non-manual }\end{array}$} & \multicolumn{2}{|c|}{ Manual } & \multicolumn{2}{|c|}{ Total } \\
\hline & $\%$ & $\mathrm{n}$ & $\%$ & $\mathrm{n}$ & $\%$ & $\mathrm{n}$ & $\%$ & $\mathrm{n}$ & $\%$ & $\mathrm{n}$ \\
\hline $16-24$ & 3.2 & 18 & 4.5 & 25 & 3.1 & 17 & 4.5 & 25 & 15.3 & 85 \\
\hline $25-34$ & 3.2 & 18 & 4.5 & 25 & 3.4 & 19 & 4.8 & 6 & 15.9 & 88 \\
\hline $35-44$ & 3.7 & 20 & 5.3 & 29 & 3.9 & 21 & 5.5 & 30 & 18.4 & 100 \\
\hline $45-54$ & 3.4 & 19 & 5.0 & 28 & 3.4 & 19 & 5.0 & 28 & 16.8 & 94 \\
\hline $55-64$ & 2.7 & 15 & 3.8 & 21 & 2.7 & 15 & 4.0 & 22 & 13.2 & 73 \\
\hline $65+$ & 3.5 & 19 & 5.0 & 28 & 4.8 & 26 & 7.0 & 39 & 20.3 & 112 \\
\hline Total & 19.7 & 109 & 28.1 & 156 & 21.3 & 117 & 30.8 & 170 & 99.9 & 552 \\
\hline
\end{tabular}

The age, gender and social class distribution of the population of the North East of England was abstracted from the results of the latest UK decennial census, conducted in April 2001. This distribution was then used to determine how many individuals would be in each age, gender and social class group in a sample of 550 individuals which was representative of the population in terms of these variables.

smoking in the following locations: pubs and clubs, restaurants and cafes, shopping malls, outdoor spaces, at home and in the workplace.

The BBC stipulated that the sample should include at least 500 individuals. A quota sampling technique was used to ensure that the sample was representative of the population of the North East of England in general in terms of age, gender and social class. This technique is illustrated in Table 2. Interviewers were instructed to approach appropriate individuals in order to meet the quota requirements. Individuals not currently resident in the North East of England were excluded as were those under 16 years of age (the current legal age for purchasing cigarettes in the UK).

\section{RESULTS}

\section{Sample characteristics}

A total of 538 individuals agreed to take part in the survey. The gender, age, social class and smoking profile of the sample are shown in Table 3, as well as comparable figures from the original quota and the population of the North East in general. There was some indication of over representation of younger individuals and individuals in non-manual social classes with associated under representation of older individuals and those in manual social classes in the sample. However, only the overrepresentation of individuals in non-manual classes and associated under representation of individuals in manual classes reached statistical significance $\left(\chi^{2}=10.151, \mathrm{df}=1, \mathrm{p}<0.01\right)$.

Support for an overall ban on smoking in pubic places Overall, $332(63.0 \%)$ individuals said they would support a general ban on smoking in public places. The variations in support for a general ban by gender, age group, social class and current smoking status and support for a general ban on smoking in public places, is shown in the first data column of Table 4. Whilst there was no difference in support for a general ban according to gender $\left.\chi^{2}=0.152, \mathrm{df}=1, \mathrm{p}>0.05\right)$ or age group $\left(\chi^{2}=2.278, \mathrm{df}=5, \mathrm{p}>0.05\right)$, support did vary by smoking status $\left(\chi^{2}=68.215, \mathrm{df}=1, \mathrm{p}<0.01\right)$ and social class $\left.\chi^{2}=6.364, \mathrm{df}=1, \mathrm{p}<0.01\right)$ with current smokers and those in manual occupations being more likely to support a ban.

\section{Support for bans on smoking in specific public places}

When individuals were asked about their support for bans on smoking in specific places, support varied according to the location named - as shown in the remaining six columns of Table 4. Support was greatest for a ban on smoking in restaurants and cafes (423 individuals, $83.1 \%$, in support of ban) and least for a ban on smoking in outdoor public spaces $(116,22.8 \%$, in support of ban). There were consistent variations in support for bans in specific places according to smoking status with non-smokers being more likely to support bans in all specified locations than current smokers (pubs and clubs: $\chi^{2}=21.113, \mathrm{df}=1, \mathrm{p}<0.01$; restaurants and cafes: $\chi^{2}=26.350, \mathrm{df}=1, \mathrm{p}<0.01$; shopping malls: $\chi^{2}=24.167, \mathrm{df}=1, \mathrm{p}<0.01 ;$ outside: $\chi^{2}=11.809, \mathrm{df}=1$, $\mathrm{p}<0.01$; home: $\chi^{2}=19.431, \mathrm{df}=1, \mathrm{p}<0.01$; workplace: $\left.\chi^{2}=36.144, \mathrm{df}=1, \mathrm{p}<0.01\right)$. Variations in support according to social class were seen in relation to bans on smoking in pubs and clubs $\left.\chi^{2}=10.452, \mathrm{df}=1, \mathrm{p}<0.01\right)$, shopping malls $\left.\chi^{2}=14.199, \mathrm{df}=1, \mathrm{p}<0.01\right)$ and in the workplace $\left(\chi^{2}=11.031, \mathrm{df}=1, \mathrm{p}<0.01\right)$ with individuals in non-manual social classes being more likely to support bans than those in manual social classes. There was some evidence that support for bans on smoking in specific locations varied by age but there were no consistent trends. 
Reasons for supporting or not supporting a ban on smoking in public places

Of the 332 individuals who stated that they would support a ban on smoking in public places, the most common reason given for supporting such a ban was concern for the health of others - cited by 191 (57.5\%). Benefits to the respondent's own health were mentioned as a reason for supporting a ban by $163(49.1 \%)$ and a general dislike of tobacco smoke was mentioned by 133 (40.1\%) respondents.

Of the 206 individuals who would not support a ban on smoking in public places, the three most common reasons mentioned for holding this view were that such a ban infringed civil liberties, cited by $101(49.0 \%)$ respondents, that the respondent was a smoker, cited by $74(35.9 \%)$ respondents, and that such a ban was not enforceable, cited by 27 (13.1\%) respondents.

\section{DISCUSSION}

\section{Summary of results}

In this survey of 538 adults living in the North East of England, we found that $63 \%$ would support a general ban on smoking in public places. Support for such a ban varied according to smoking status and social class with smokers and individuals in manual occupations being less likely to support a ban. When participants were asked about bans on smoking in a variety of different locations, support for a ban varied according to the specific location. Support was strongest for a ban on smoking in restaurants, shopping malls and the workplace. There was little support for a ban on smoking in pubs and clubs, outside places and in the home.

\section{Limitations of methods}

The survey was designed to be as representative as possible of the population of the North East of England.
However, the sample obtained was over-representative of younger age-groups and of people in non-manual social classes. This may be because data was collected from urban shopping areas, where individuals in nonmanual occupations may be more likely to be at the time the survey was undertaken - weekday lunch times. Despite the use of the quota method to guide the types of individuals to be approached for inclusion in the survey, it is also possible that there was some selection bias with researchers tending to approach individuals who were similar to themselves - young and in nonmanual occupations. In addition, there may have been some variation in response to the invitation to take part in the survey with older individuals and those in manual occupations being less likely to agree to take part.

No formal power calculation was carried out. However the study was adequately powered to detect a number of important variations in support of a ban on smoking in public places.

\section{Interpretation of results in the light of previous work}

Despite the limitations in the methods identified, the survey represents a fair assessment of local public opinion concerning bans on smoking in public places. Two population based postal surveys have assessed attitudes to smoking restrictions in public places over the last 15 years in restricted parts of the North East of England - the Newcastle Health and Lifestyle survey in 1991(13) and the Tees Health and Lifestyle survey in 2000 (14). Based on samples of more than 4000 in both cases, these surveys found that $44 \%$ and $50 \%$ of respondents respectively thought that there should be more restrictions on smoking in public places. This is less than the $63 \%$ found in our study and may reflect the general trend over time towards lower smoking rates and higher support for smoking bans and restrictions (15).

Table 3. Sample characteristics

\begin{tabular}{llllll}
\hline & & N in sample & N in quota & \% of sample & $\begin{array}{l}\text { \% in North East } \\
\text { of England }\end{array}$ \\
\hline Gender & Male & 259 & 287 & 49.1 & 47.9 \\
& Female & 268 & 263 & 50.9 & 52.1 \\
\hline \multirow{2}{*}{ Age group } & $16-24$ & 104 & 84 & 19.9 & 15.3 \\
& $25-34$ & 88 & 87 & 16.9 & 15.9 \\
& $35-44$ & 97 & 102 & 18.6 & 16.4 \\
& $45-54$ & 87 & 92 & 16.7 & 13.2 \\
& $55-64$ & 62 & 112 & 11.9 & 20.3 \\
\hline \multirow{2}{*}{ Social class } & $65+$ & 84 & 226 & 41.0 \\
& Non manual & 259 & 326 & 49.2 & 59.0 \\
\hline Smoking status & Manual & 252 & Not stated in quota & 36.9 & 29.0 \\
& Smoker & 189 & Not stated in quota & 63.1 & 71.0 \\
\hline
\end{tabular}


Table 4. Support for bans on smoking in public places

\begin{tabular}{|c|c|c|c|c|c|c|}
\hline & Overall & & Pubs \& clubs & Restaurants \& cafes & Shopping n & nalls \\
\hline All respondents & $\begin{array}{l}\mathrm{N}(\%) \\
332(63.0)\end{array}$ & $\chi^{2}(\mathrm{df})$ & $\begin{array}{l}\mathrm{N}(\%) \quad \chi^{2}(\mathrm{df}) \\
189(37.1)\end{array}$ & $\begin{array}{ll}\mathrm{N}(\%) & \chi^{2}(\mathrm{df}) \\
423(83.1) & \end{array}$ & $\begin{array}{l}\mathrm{N}(\%) \\
368(72.3)\end{array}$ & $\chi^{2}(\mathrm{df})$ \\
\hline $\begin{array}{l}\text { Gender } \\
\qquad \begin{array}{l}\text { Male } \\
\text { Female }\end{array}\end{array}$ & $\begin{array}{l}165(64.0) \\
167(62.3)\end{array}$ & $0.152(1)$ & $\begin{array}{l}96(38.2) \\
92(36.1)\end{array}$ & $\begin{array}{l}207(82.5) \\
213(83.5) 0.101(1)\end{array}$ & $\begin{array}{l}180(71.7) \\
187(73.3)\end{array}$ & $0.167(1)$ \\
\hline $\begin{array}{l}\text { Age group } \\
\begin{aligned} 16-24 \\
25-34 \\
35-44 \\
45-54 \\
55-64 \\
65+\end{aligned}\end{array}$ & $\begin{array}{l}64(61.5) \\
50(56.8) \\
63(65.6) \\
57(65.5) \\
39(62.9) \\
55(65.5)\end{array}$ & 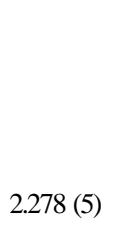 & $\begin{array}{l}33(33.0) \\
18(20.7) \\
41(44.1) \\
31(37.8) \\
26(44.1) \\
37(46.3) \quad 16.815 \dagger(5)\end{array}$ & $\begin{array}{l}82(82.0) \\
62(71.3) \\
80(86.0) \\
69(84.1) \\
51(86.4) \\
71(88.8) 11.512 *(5)\end{array}$ & $\begin{array}{l}72(72.0) \\
63(72.4) \\
67(72.0) \\
65(79.3) \\
41(69.5) \\
54(67.5)\end{array}$ & 3.145 (5) \\
\hline $\begin{array}{l}\text { Social class } \\
\text { Non-man. } \\
\text { Manual }\end{array}$ & $\begin{array}{l}176(68.0) \\
145(57.8)\end{array}$ & $6.364 *(1)$ & $\begin{array}{l}101(40.1) \\
77(32.2) \quad 10.452 \dagger(1)\end{array}$ & $\begin{array}{l}212(84.1) \\
197(82.4) 0.471(1)\end{array}$ & $\begin{array}{l}202(80.2) \\
156(65.3)\end{array}$ & $14.199 \dagger(1)$ \\
\hline $\begin{array}{l}\text { Smoking status } \\
\text { Current } \\
\text { Non }\end{array}$ & $\begin{array}{l}75(39.9) \\
247(76.5)\end{array}$ & $68.215+(1)$ & $\begin{array}{l}40(22.9) \\
138(43.7) 21.113 \dagger(1)\end{array}$ & $\begin{array}{l}125(71.4) \\
283(89.6) 26.350 \dagger(1)\end{array}$ & $\begin{array}{l}104(59.4) \\
253(80.1)\end{array}$ & $24.167 \dagger(1)$ \\
\hline
\end{tabular}

*statistically significant at the $5 \%$ level ; †statistically significant at the $1 \%$ level; df = degrees of freedom

A further annual national survey of around 3500 people, conducted by the UK Office for National Statistics (ONS), (15) has found gradual increases in support for smoking restrictions since 1996. As with the present results, support in this survey has consistently been greatest for increased smoking restrictions in restaurants with $88 \%$ of respondents agreeing that smoking should be restricted in restaurants in the 2002 survey. Like the present work, the ONS survey reported marked trends in support for smoking restrictions according to smoking status and occupational social class. However, support for smoking restrictions in the ONS survey is consistently higher than support for smoking bans found in our work - for example, $54 \%$ of respondents said that there should be more restrictions on smoking in pubs and clubs in the ONS survey, compared to $37 \%$ supporting a ban in these places in our survey. There are three possible reasons for this. Firstly, the national survey asked respondents about smoking restrictions whilst our survey used the term 'ban on smoking'. The less severe nature of smoking restrictions, compared to smoking bans, with the implication that smoking will be allowed, but just restricted to certain areas, may account for the larger proportion of people supporting restrictions in the ONS survey compared to bans in our work. In addition, both surveys found that current smokers were less likely to support bans or restrictions on smoking and it is possible that the higher smoking rates in the North East of England, compared to the UK as a whole, explain some of the differences in absolute levels of support for smoking restrictions and bans $-36 \%$ of respondents in our survey were smokers compared to $25 \%$ of those in the ONS survey.

\section{Implications of results}

Banning smoking in public places is one way to reduce both overall smoking rates and exposure to second hand smoke $(2,3)$. However, recent work has concluded that such policies work best when there is strong public support for them (3). Assessing local support for bans on smoking in public places is, therefore, an important preliminary step before a decision is made on implementation. Our results suggest that there is strong local support in the North East of England for bans on smoking in restaurants and cafes, shopping malls and workplaces and that bans in these areas will probably be enforceable and, therefore, effective. There was much less support for bans on smoking in pubs and clubs, outside and in the home and introducing bans in these places would probably be much harder to enforce and, therefore, much less effective.

Although these findings seem clear cut, there is one possible, important conflict - that of individuals working in pubs and clubs. Pubs and clubs are not just entertainment and leisure venues, they are also workplaces. If bans on smoking were to be introduced in all workplaces, this would have to include pubs and clubs - something that might not be acceptable to the majority of customers. Any mandatory bans would have to take possible conflicts such as these into account and further research may be needed to determine the best way to resolve such problems. 
Table 4. Support for bans on smoking in public places

\begin{tabular}{|c|c|c|c|c|c|c|}
\hline & Outside & & Home & & Workplace & \\
\hline All respondents & $\begin{array}{l}\mathrm{N}(\%) \\
116(22.8)\end{array}$ & $\chi^{2}(\mathrm{df})$ & $\begin{array}{l}\mathrm{N}(\%) \\
138(27.1)\end{array}$ & $\chi^{2}(\mathrm{df})$ & $\begin{array}{l}\mathrm{N}(\%) \\
361(71.6)\end{array}$ & $\chi^{2}(\mathrm{df})$ \\
\hline \multicolumn{7}{|l|}{ Gender } \\
\hline Male & $59(23.5)$ & & $75(29.9)$ & & $173(69.5)$ & \\
\hline Female & $57(22.4)$ & $0.095(1)$ & $62(24.3)$ & $1.985(1)$ & $187(74.2)$ & $1.385(1)$ \\
\hline \multicolumn{7}{|l|}{ Age group } \\
\hline $16-24$ & $27(27.0)$ & & $19(19.0)$ & & $74(76.3)$ & \\
\hline $25-34$ & $20(23.0)$ & & $16(18.4)$ & & $59(68.6)$ & \\
\hline $35-44$ & $21(22.6)$ & & $31(34.4)$ & & $66(71.0)$ & \\
\hline $45-54$ & $24(29.3)$ & & $27(32.9)$ & & $57(69.5)$ & \\
\hline $55-64$ & $10(16.9)$ & & $13(22.0)$ & & $42(72.4)$ & \\
\hline $65+$ & $13(16.3)$ & $6.018(5)$ & $29(36.3)$ & $14.762^{*}(5)$ & $57(71.3)$ & $1.645(5)$ \\
\hline \multicolumn{7}{|l|}{ Social class } \\
\hline Non-man. & $59(23.4)$ & & $68(27.0)$ & & $196(78.4)$ & \\
\hline Manual & $52(21.8)$ & $1.512(1)$ & $65(27.2)$ & $0.018(1)$ & $154(65.0)$ & $11.031 \dagger(1)$ \\
\hline \multicolumn{7}{|l|}{ Smoking status } \\
\hline Current & $24(13.7)$ & & $26(14.9)$ & & $95(55.2)$ & \\
\hline Non & $86(27.2)$ & $11.809+(1)$ & $105(33.2)$ & $19.431 \dagger(1)$ & $254(80.9)$ & $36.144 \dagger(1)$ \\
\hline
\end{tabular}

*statistically significant at the $5 \%$ level ; † statistically significant at the $1 \%$ level; $\mathrm{df}=$ degrees of freedom

\section{CONCLUSIONS}

Local support for bans on smoking in public places in the North East of England is relatively high although varies according to smoking status and occupational social class. Support is strongest for bans on smoking in restaurants and cafes, shopping malls and workplaces. Introduction and enforcement of smoking bans in these locations would not be expected to meet with great opposition and may have a positive influence on public health.

\section{ACKNOWLEDGEMENTS}

The following stage 3 medical students at Newcastle University contributed to the development of methods, data collection and data entry but did not qualify for authorship: James Allan, Paula Bradley, Jonathon Bridges, Papari Deka and Fiona Fahey. Many thanks to Marion Hancock, Diane Donaldson, Fraser Chalmers and Ruth Wood of Newcastle University for administrative and technical support.

\section{FUNDING}

This study was partially funded by BBC North East and Cumbria.

\section{REFERENCES}

1. Jamison D, Creese A and Prentice T. The world health report 1999: making a difference. France: World Health Organization, 1999.

2. Donaldson L. Annual report of the Chief Medical Officer 2002. London: Department of Health, 2003.

3. Jha $\mathrm{P}$ and Chaloupka F. The economics of global tobacco control. British Medical Journal 321:358-361; 2000

4. Ministers urged to ban public smoking. http://news.bbc.co.uk/1/hi/health/3041344.stm; 2003. Accessed: 8 October 2003

5. Doctors urge public smoking ban. http://news.bbc.co.uk/1/hi/health/3034824.stm; 2003. Accessed: 8 October 2003

6. Eisner M, Smith A and Blanc P. Bartenders' respiratory health after establishment of smoke-free bars and taverns. Journal of the American Medical Association 280:1909-1914; 1998

7. Longo D, Brownson R, Johnson J, et al. Hospital smoking bans and employee smoking behaviour: results of a national survey. Journal of the American Medical Association 275:1252-1257; 1996

8. Farkas A, Gilpin E, Distefan $\mathbf{J}$ and Pierce J. The effects of household and workplace smoking restrictions on quitting behaviours. Tobacco Control 8:261-265; 1999

9. EU public smoking ban considered. http://news.bbc.co.uk/1/hi/health/3121970.stm; 2003. Accessed: 8 October 2003

10. Jones $\mathrm{K}$, Wakefield $\mathrm{M}$ and Turnbull $\mathrm{D}$. Attitudes and experiences of restaurateurs regarding smoking bans in Adelaide, South Australia. Tobacco Control 8:62-66; 1999

11. Last smoke in New York. http://news.bbc.co.uk/1/hi/world/americas/2899719.stm; 2003. Accessed: 8 October 2003

12. Coolican H. Research methods and statistics in psychology. London; Hooder and Stoughton, 1999.

13. Harrington B, White M, Foy C, Raybould S and Harland J. The Newcastle health and lifestyle survey 1991: health and lifestyles in Newcastle. Newcastle upon Tyne: University of Newcastle upon Tyne, 1991.

14. Reilly M, Ashton V, Eynon C, Lowson D and Heywood P. Health and lifestyle Tees area 2000: are we getting healthier? Middlesbrough: Tees Health Authority, 2001.

15. Lader D and Meltzer H. Smoking related behaviour and attitudes, 2002. London: Office for National Statistics, 2003.

16. Smoking ban looms http://www.bbc.co.uk/insideout/northeast/series4/smoking_smo kingban_cigarettes_health.shtml; 2003. Accessed: 30 October 2003 